\title{
Identification of a new class of WNT1 inhibitor: Cancer cells migration, G-quadruplex stabilization and target validation
}

\author{
Lien-Cheng Chang ${ }^{1,2,3}$, Tsung-Chih Chen ${ }^{3}$, Shiag-Jiun Chen ${ }^{4}$, Chun-Liang Chen ${ }^{3}$, \\ Chia-Chung Lee ${ }^{3}$, Shih-Hsiung $\mathbf{W u}^{5}$, Yun Yen ${ }^{3}$, Hsu-Shan Huang ${ }^{3,4}$, Jing-Jer Lin ${ }^{1,6}$ \\ ${ }^{1}$ Institute of Biopharmaceutical Sciences, National Yang-Ming University, Taipei 112, Taiwan, ROC \\ ${ }^{2}$ Food and Drug Administration, Ministry of Health and Welfare, Taipei 115, Taiwan, ROC \\ ${ }^{3}$ Graduate Institute of Cancer Biology and Drug Discovery, College of Medical Science and Technology, Taipei Medical \\ University, Taipei 110, Taiwan, ROC \\ ${ }^{4}$ School of Pharmacy, National Defense Medical Center, Taipei 114, Taiwan, ROC \\ ${ }^{5}$ Institute of Biological Chemistry, Academia Sinica, Taipei 115, Taiwan, ROC \\ ${ }^{6}$ Institute of Biochemistry and Molecular Biology, National Taiwan University College of Medicine, Taipei 100, Taiwan, RoC \\ Correspondence to: Hsu-Shan Huang, email: huanghs99@tmu.edu.tw \\ Jing-Jer Lin, email: jingjerlin@ntu.edu.tw
}

Keywords: Wnt1-mediated signaling pathway, G-quadruplex, 6-substituted 9-chloro-11H-indeno[1,2-c] quinolin-11-ones, reporter assay

Received: June 14, 2015

Accepted: November 16, 2015

Published: December 15, 2015

\section{ABSTRACT}

Developing the Wnt pathway inhibitors has been considered as a therapeutic approach for cancers and other Wnt-related diseases. Previously we found that the G-rich sequence of WNT1 promoter is capable of forming G-quadruplex structure and stabilizing agents for Wnt1-mediated signaling pathway. Using a established cell-based drug screen system that enabled the evaluation of WNT1 expression activity in a G-quadruplex structure dependent manner, we evaluated a series of 6-substituted 9-chloro-11H-indeno[ $1,2-c]$ quinolin-11-one derivatives that potentially inhibit the Wnt1-mediated signaling pathway. The most potent compound SJ26 showed repression of WNT1 activity in a G-quadruplex structure-dependent manner. Moreover, compound SJ26 inhibited the WNT1-mediated downstream signaling pathway and suppressed migration activity of cancer cells. Thus, we have identified a tetracyclic azafluorenone, SJ26, that is capable of binding to G-quadruplex DNA structure, repressing WNT1 expression, and inhibiting cell migration.

\section{INTRODUCTION}

Tumor metastasis is the most common cause of cancer related-death. Targeting metastasis is considered as one of the highest priorities for researches in antitumor agents [1]. The Wnt-mediated signal pathway regulates various cellular functions, including proliferation, survival, migration, and development by trigger downstream signaling cascades [2]. Many of the Wnt-targeted genes are involved in tumorigenesis and metastasis. For example, myc and cyclin D1 are involved in proliferation and WISP1 is involved in angiogenesis [3,4]. Wrch1 and $M M P 7$ are also known to be involved in migration and invasion of cancer cells [5, 6]. Clinically, aberrant activation of Wnt signaling is observed in a variety of tumors. Previous studies reported that high levels of WNT1 expression in patients are associated with advanced metastasis [7-9]. and the overall survival is lower in patients with Wnt1-positive cancer. Thus, developing the Wnt pathway inhibitors has been considered as a therapeutic approach for the treatment of patients with cancers and other Wnt-related diseases $[10,11]$.

Small molecule inhibitors of the Wnt signaling pathways have been designed to target mediators of Wntsignaling pathway [11]. These compounds mainly aim to decrease the levels of $\beta$-catenin [12-16]. Agents targeting Wnt directly have also been developed. For example, the anti-Wnt1 antibody was used to block the stimulation 
of Wnt1 downstream signaling pathway. Treatment of anti-Wnt1 antibody was shown to reduce the growth of hepatocellular carcinoma and colorectal cancer both in vivo and in vitro $[17,18]$.

Previous our study reported that the G-rich sequence of WNT1 promoter is capable of forming both hairpin and G-quadruplex structures in the presence of potassium ion [19, 20]. Significantly, the Wnt1-mediated signaling pathway can be repressed upon the addition of G-quadruplex stabilizing agents in cancer cells. Consequently, the migration and invasion activities of cancer cells were also decreased [19]. Thus, it is likely that suppression of tumor metastasis can be achieved through stabilizing the G-quadruplex forming sequence located at the WNT1 promoter.

Diverse anthracycline derivatives (e.g. doxorubicin, daunorubicin, mitoxantrone and ametantrone) have been shown to have anti-proliferative (or cytostatic) properties. We and others showed that the structurally related anthraquinone compounds can stabilize G-quadruplex structure formed by telomeric DNA sequences and inhibit telomerase or topoisomerase activity [21-33]. Camptothecin (CPT) and TAS-103 are also cytotoxic quinoline alkaloid derivatives that show potent topoisomerase (topo) I and/or topo II inhibition activities [34-37]. Two related CPT family members, irinotecan and topotecan, are currently used clinically as anticancer chemotherapy drugs $[38,39]$. Based on the structures of anthracycline, here we design and synthesize a series of 6-substituted 9-chloro-11H-indeno[1,2-c] quinolin-11-one derivatives by varying the side chains with heterocyclic amine moieties and lipophilic alkyl chains (Figure 1). We have also integrated the pharmocophore of camptothecin (CPT) and TAS-103 into our drug design [40, 41]. The synthesis and results of these series of compounds against various cell lines and other SAR evaluation will be reported in a separate paper. In this study, the G-quadruplex structure-dependent WNT1 repression activities of these newly synthesized compounds were analyzed by a cell-based assay system. We found that compound SJ26 showed potent inhibitory effects to the Wnt1-mediated downstream signaling pathway in a G-quadruplex structure dependent manner and inhibited the migration activity of cancer cells. Our results suggested the tetracyclic azafluorenones are potent $W N T 1$ repressors.

\section{RESULTS}

\section{Cell-based system for expression repressors of WNT1 gene}

Functional analysis of human WNT1 proximal promoter using reporter assays revealed that the 277-bp upstream sequence of WNT1 is sufficient for the control of developmentally regulated expression [42, 43]. Sequence analysis of the 277-bp sequence identified two TATA boxes and a stretch of extremely G-rich sequence.
Significantly, the G-rich sequence of the WNT1 promoter contains four runs of at least three contiguous guanines that are capable of forming G-quadruplex structures under physiological conditions [19, 20].

To facilitate the analysis of WNT1 expression, we ligated downstream to the WNT1 promoter a reporter gene, SEAP, to generate a WNT1 promoterdriven reporter construct, pWNT1-SEAP. We have also constructed two mutants that failed to form G-quadruplex structure, $\mathrm{m} 1$ and $\mathrm{m} 6$ (Figure 2A). The expression of SEAP can then be used as the criterion for the measurement of wild-type and mutant WNT1 expression efficiency. Stable human lung carcinoma cell (H1299) lines carrying wild-type or mutant plasmids were selected. Although reporter analysis using transient transfection method to introduce reporter plasmids into cells produces better results in general, the approach is not suitable for drug screening because it needs additional steps for the analysis. These additional steps are prone to introduce variations in the screens. Moreover, transfection step requires additional reagents that are not economic for large-scale screens. Thus, stable clones were employed in drug screens.

The basal phosphatase activities under the control of wild-type or mutants promoters were first analyzed. We detected similar phosphatase activities for wild-type, the Wnt1-m1, and the Wnt1-m6 promoters, suggesting that the mutation did not affect the general transcriptional activity of the WNT1 promoter (Figure 2B). To test if our reporter system is capable of differentiate G-quadruplex structuremediated repression of WNT1 expression, the SEAP expression was monitored in the presence of 3,6-bis(1methyl-4-vinylpyridinium) carbazole diiodide (BMVC) because it was shown to bind and stabilize the G-quadruplex structure at WNT1 promoter [19]. Upon treatment with BMVC, the expressions of SEAP from the wild-type promoter were reduced (Figure 2C). In contrast, the expression efficiency of mutant promoters did not respond to BMVC treatments. Thus, formation of G-quadruplex structure is required for suppressing WNT1 expression by BMVC. This result indicated that our reporter construct is capable of monitoring the expression of WNT1. Moreover, addition of WNT1-m1 and -m6 mutation enables the evaluation of whether the repression requires G-quadruplex structure. Thus, the cells harboring pWNT1-SEAP or its mutants could be used as a tool to monitor the expression of WNT1 in a G-quadruplex structure dependent manner.

\section{Inhibitory effect of compound SJ26 on the WNT1 expression of G-quadruplex dependent manner}

The expression of SEAP in H1299 cells harboring these reporters were used as the criterion to evaluate if the 6-substituted 9-chloro-11H-indeno[1,2-c] quinolin-11-one derivatives repressed the expression of WNT1 in cancer cells. To facilitate effective identification of compounds 
<smiles>[R]CC(=O)[C@]1(O)Cc2c(O)c3c(c(O)c2[C@@H](O[C@H]2C[C@H](N)[C@H](O)[C@H](C)O2)C1)C(=O)c1cccc(OC)c1C3=O</smiles>

Doxorubicin, $\mathrm{R}=\mathrm{OH}$ Daunorubicin, $\mathrm{R}=\mathrm{H}$<smiles>[R]c1ccc2nc3c(c([R3])c2c1[R2])Cn1c-3cc2c(c1=O)COC(=O)[C@]2(O)CC</smiles>

Camptothecin, $\mathbf{R}_{\mathbf{1}}=\mathbf{R}_{\mathbf{2}}=\mathbf{R}_{\mathbf{3}}=\mathrm{H}$ Topotecan, $\mathrm{R}_{1}=\mathrm{OH} ; \mathrm{R}_{2}=\mathrm{CH}_{2} \mathrm{~N}\left(\mathrm{CH}_{3}\right)_{2}, \mathrm{R}_{3}=\mathrm{H}$

Mitoxantrone, $\mathrm{X}=\mathrm{OH}$

Ametantrone, $\mathrm{X}=\mathrm{H}$

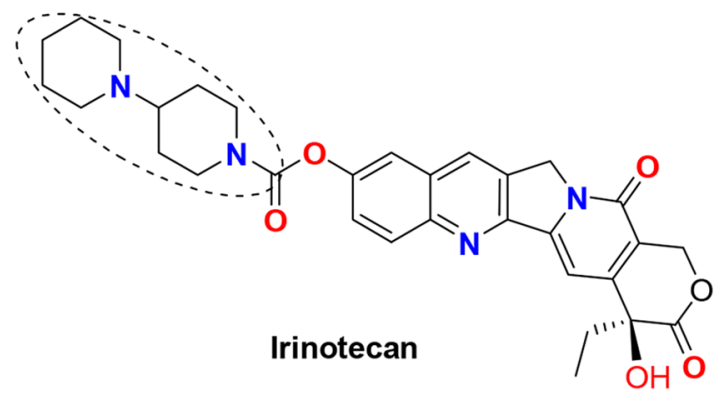<smiles>Cc1ccc2nc(N)sc2c1</smiles><smiles>CC=NCC</smiles><smiles>Cc1cncc(CC(=O)Nc2ccc(-c3cnccn3)cn2)c1</smiles><smiles>NC(=O)CSc1nc2c(c(=O)n1-c1ccccc1)SCC2</smiles>

IWP-2<smiles>COc1ccc(C(=O)C2CCN(CC(=O)N(Cc3nc4c(c(=O)[nH]3)COCC4)CC3CC3)CC2)cc1</smiles>
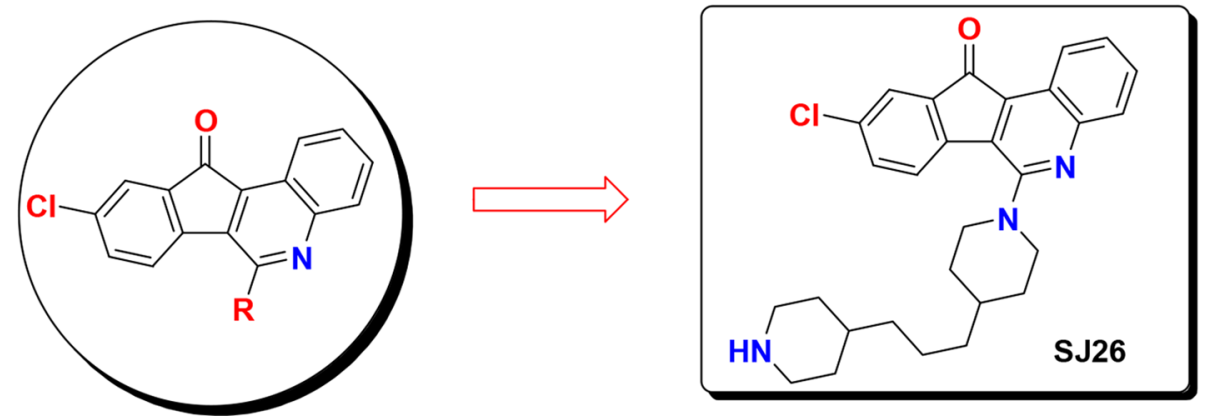

Figure 1: Chemical structures of several known tetracyclic quinoline derivatives, topoisomerase I inhibitors and Wnt modulators. 
that selectively repress $W N T 1$ activity, we established a screening strategy that was adopted and modified from the NCI-60 Human Tumor Cell Lines Screen (https://dtp. cancer.gov/discovery_development/nci-60/methodology. htm). The relative $W N T 1$ expressions by these compounds at one-dose $(10 \mu \mathrm{M})$ were first determined in these cells. We reasoned that an effective inhibitor should give good inhibitory effect at this concentration. The numbers reported (values between 0 and 100) for the one-dose assays represented the $W N T 1$ promoter activities relative to the no-drug control that were determined by SEAP assays (Table 1). To rule out compounds that showed apparent SEAP repression activities by inhibiting cell growth, MTT assays were also introduced into our screen. It is to eliminate compounds that showed WNT1 repressing activities non-selectively. Compounds that exhibited significant $W N T 1$ promoter inhibition and did not show grow inhibitory activity in the one-dose screen are selected and further evaluated.

As shown in Table 1, more than half [13 out of 25 including: SJ3 (17.1\%), SJ4 (17.4\%), SJ5 (23.0\%), SJ6 (33.3\%), SJ7 (34.0\%), SJ10 (30.1\%), SJ17 (38.4\%), SJ18 (34.5\%), SJ21 (24.7\%), SJ22 (47.1\%), SJ23 (49.2\%), SJ26 (42.7\%), and SJ27 (42.0\%)] of the tested compounds repressed more than $50 \%$ of the SEAP activity in wild-type WNT1 promoter, suggesting that this series of analogs are potent repressors of WNT1 expression. At $10 \mu \mathrm{M}$ concentration, none of the synthesized derivatives showed potent cytotoxicity, indicating that the observed WNT1 repressing activities were not due to cellular toxicity (Table 1). To identify compounds that repressed WNT1 expression through the
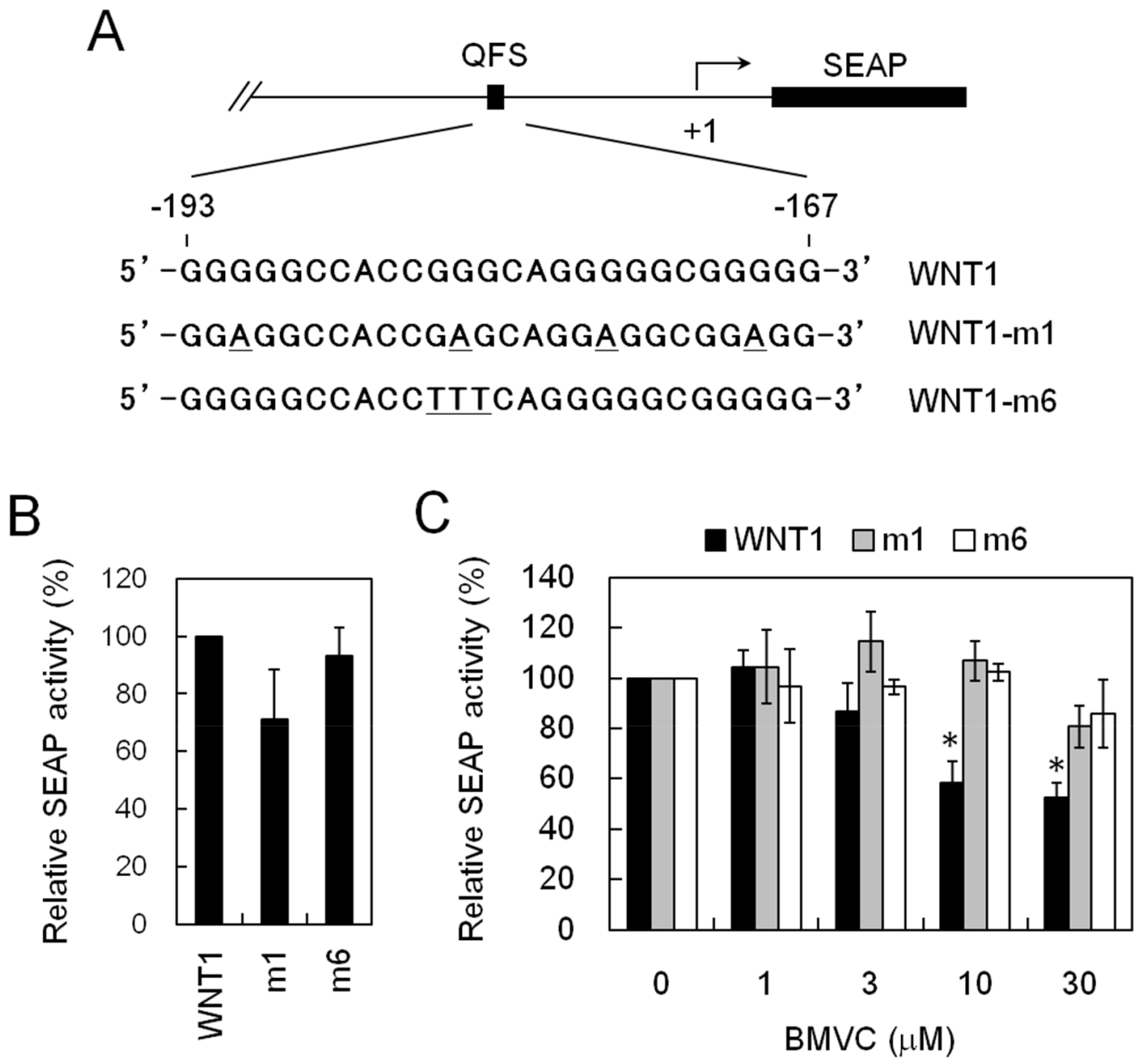

Figure 2: Establishing a cell-based assay system that inhibits $W N T 1$ expression through stabilizing the G-quadruplex structure formed at its promoter. A. Schematic diagrams showed the mutation sites of $W N T 1$ in reporter assays. The G-quadruplexforming sequences of Wnt1 (wild-type), Wnt1-m1, or Wnt1-m6 (Wnt1 mutations) were indicated. B. Wnt1-m1 and m6 mutations did not affect the basal expression level of WNT1. The H1299 cells harboring wild-type, WNT1-m1, and Wnt1-m6 reporters were analyzed for their basal expression activity. The relative phosphatase activities of wild-type, WNT1-m1, and WNT1-m6 mutant were presented using the wild-type level as $100 \%$. C. BMVC repressed WNT1 expression required G-quadruplex structure formation. The H1299 cells harboring wild-type, WNT1-m1, and WNT1-m6 reporters were incubated with the indicated concentrations of BMVC for 2 days. The phosphatase activities were then analyzed using the activity of DMSO-treated cells as $100 \%$. Asterisks indicate $p<0.05$. 
Table 1: Effect of tetracyclic azafluorenone derivatives on repressing $W N T 1$ expression

\begin{tabular}{|c|c|c|c|c|c|c|c|}
\hline \multirow{3}{*}{$\begin{array}{l}\text { Compd } \\
\text { SJ }\end{array}$} & \multirow{3}{*}{$\mathbf{R}$} & \multicolumn{6}{|c|}{ H1299 ${ }^{a}$} \\
\hline & & \multicolumn{3}{|c|}{$\operatorname{SEAP}(\% \pm \mathbf{S D})^{b}$} & \multicolumn{3}{|c|}{ MTT $(\% \pm$ SD) } \\
\hline & & Wnt1 & $\mathbf{m} 1^{c}$ & m6 & Wnt1 & m1 & m6 \\
\hline 2 & $-\mathrm{Cl}$ & $94.7 \pm 34.9$ & $96.22 \pm 21.4$ & $157.8 \pm 20.6$ & $\begin{array}{c}114.5 \pm \\
3.0\end{array}$ & $\begin{array}{c}101.0 \pm \\
17.2\end{array}$ & $132.9 \pm 7.5$ \\
\hline 3 & $-\mathrm{NHCH}_{3}$ & $17.1 \pm 10.0$ & $49.0 \pm 10.8$ & $32.6 \pm 17.4$ & $92.9 \pm 4.9$ & $\begin{array}{c}139.2 \pm \\
20.5\end{array}$ & $90.9 \pm 5.5$ \\
\hline 4 & $-\mathrm{N}\left(\mathrm{CH}_{3}\right)_{2}$ & $17.4 \pm 9.1$ & $79.4 \pm 14.9$ & $35.3 \pm 21.5$ & $\begin{array}{c}101.2 \pm \\
2.3\end{array}$ & $\begin{array}{c}137.5 \pm \\
16.2\end{array}$ & $83.8 \pm 3.2$ \\
\hline 5 & $-\mathrm{NHCH}_{2} \mathrm{CH}_{2} \mathrm{~N}\left(\mathrm{CH}_{2} \mathrm{CH}_{3}\right)_{2}$ & $23.0 \pm 2.4$ & $25.7 \pm 12.4$ & $45.5 \pm 26.3$ & $97.1 \pm 4.6$ & $\begin{array}{c}113.9 \pm \\
18.9\end{array}$ & $76.8 \pm 5.5$ \\
\hline 6 & $-\mathrm{N}\left(\mathrm{CH}_{2} \mathrm{CH}_{2}\right)_{2}$ & $33.3 \pm 11.5$ & $76.5 \pm 18.6$ & $34.2 \pm 21.2$ & $\begin{array}{c}104.9 \pm \\
1.0\end{array}$ & $\begin{array}{c}102.9 \pm \\
6.6\end{array}$ & $81.9 \pm 8.3$ \\
\hline 7 & $-\mathrm{N}\left(\mathrm{CH}_{2} \mathrm{CH}_{2}\right)_{2} \mathrm{CH}_{2}$ & $34.0 \pm 14.7$ & $75.1 \pm 19.8$ & $53.6 \pm 15.7$ & $\begin{array}{c}113.8 \pm \\
11.1\end{array}$ & $\begin{array}{c}151.1 \pm \\
1.0\end{array}$ & $92.0 \pm 14.7$ \\
\hline 8 & $-\mathrm{N}\left(\mathrm{CH}_{2} \mathrm{CH}_{2}\right)_{2} \mathrm{CHCH}_{3}$ & $57.6 \pm 7.1$ & $98.7 \pm 31.1$ & $58.1 \pm 17.4$ & $\begin{array}{c}105.3 \pm \\
10.9\end{array}$ & $\begin{array}{c}163.8 \pm \\
7.0\end{array}$ & $\begin{array}{c}104.3 \pm \\
14.1\end{array}$ \\
\hline 9 & $-\mathrm{N}\left(\mathrm{CH}_{2} \mathrm{CH}_{2} \mathrm{CH}_{2}\right)_{2}$ & $55.8 \pm 13.9$ & $85.8 \pm 37.0$ & $57.4 \pm 15.8$ & $\begin{array}{c}118.2 \pm \\
7.0\end{array}$ & $\begin{array}{c}148.7 \pm \\
1.0\end{array}$ & $96.6 \pm 6.8$ \\
\hline 10 & $-\mathrm{N}\left(\mathrm{CH}_{2} \mathrm{CH}_{2}\right)_{2} \mathrm{O}$ & $30.1 \pm 9.5$ & $79.1 \pm 18.1$ & $46.7 \pm 15.5$ & $98.0 \pm 9.0$ & $\begin{array}{c}119.6 \pm \\
16.4\end{array}$ & $95.9 \pm 3.6$ \\
\hline 11 & $-\mathrm{N}\left(\mathrm{CH}_{2} \mathrm{CH}_{2}\right)_{2} \mathrm{~S}$ & $55.7 \pm 14.7$ & $115.5 \pm 21.9$ & $53.8 \pm 13.4$ & $\begin{array}{c}109.0 \pm \\
5.6\end{array}$ & $\begin{array}{c}154.2 \pm \\
15.2\end{array}$ & $110.8 \pm 3.5$ \\
\hline 12 & $-\mathrm{N}\left(\mathrm{CH}_{2} \mathrm{CH}_{2}\right)_{2} \mathrm{NH}$ & $76.2 \pm 13.4$ & $103.5 \pm 4.8$ & $63.5 \pm 13.1$ & $\begin{array}{c}88.8 \pm \\
13.1\end{array}$ & $\begin{array}{c}131.6 \pm \\
23.1\end{array}$ & $105.4 \pm 9.0$ \\
\hline 13 & $\begin{array}{l}-\mathrm{N}\left[\mathrm{CH}\left(\mathrm{CH}_{3}\right) \mathrm{CH}_{2}\right]\left(\mathrm{CH}_{2} \mathrm{CH}_{2}\right) \\
\mathrm{NH}\end{array}$ & $60.7 \pm 0.9$ & $115.3 \pm 2.8$ & $64.6 \pm 3.0$ & $\begin{array}{c}120.1 \pm \\
8.3\end{array}$ & $\begin{array}{c}161.0 \pm \\
0.3\end{array}$ & $100.3 \pm 9.2$ \\
\hline 14 & $-\mathrm{N}\left(\mathrm{CH}_{2} \mathrm{CH}_{2}\right)_{2} \mathrm{NCH}_{3}$ & $73.1 \pm 7.9$ & $64.7 \pm 22.1$ & $50.1 \pm 19.1$ & $99.8 \pm 1.2$ & $\begin{array}{c}145.3 \pm \\
3.7\end{array}$ & $92.4 \pm 1.1$ \\
\hline 15 & $-\mathrm{N}\left(\mathrm{CH}_{2} \mathrm{CH}_{2}\right)_{2} \mathrm{NCH}_{2} \mathrm{CH}_{3}$ & $78.7 \pm 11.4$ & $110.3 \pm 9.8$ & $48.6 \pm 17.0$ & $\begin{array}{c}112.5 \pm \\
0.0\end{array}$ & $\begin{array}{c}153.6 \pm \\
21.0\end{array}$ & $113.8 \pm 5.2$ \\
\hline 16 & $\begin{array}{l}-\mathrm{N}\left(\mathrm{CH}_{2} \mathrm{CH}_{2}\right)_{2} \mathrm{NCH}\left(\mathrm{CH}_{2}\right. \\
\left.\mathrm{CH}_{2}\right)_{2}\end{array}$ & $57.3 \pm 14.0$ & $131.8 \pm 30.4$ & $76.3 \pm 7.8$ & $\begin{array}{c}121.0 \pm \\
6.6\end{array}$ & $\begin{array}{c}169.7 \pm \\
14.0\end{array}$ & $120.0 \pm 4.6$ \\
\hline 17 & $\begin{array}{l}-\mathrm{N}\left(\mathrm{CH}_{2} \mathrm{CH}_{2}\right)_{2} \mathrm{CHN} \\
\left(\mathrm{CH}_{2} \mathrm{CH}_{2}\right)_{2} \mathrm{CH}_{2}\end{array}$ & $38.4 \pm 19.5$ & $20.8 \pm 14.0$ & $51.3 \pm 19.6$ & $\begin{array}{c}112.9 \pm \\
3.9\end{array}$ & $\begin{array}{c}157.8 \pm \\
8.3\end{array}$ & $115.8 \pm 9.8$ \\
\hline 18 & $-\mathrm{N}\left(\mathrm{CH}_{2} \mathrm{CH}_{2}\right)_{2} \mathrm{NC}_{6} \mathrm{H}_{5}$ & $34.5 \pm 13.8$ & $49.4 \pm 7.8$ & $74.2 \pm 12.9$ & $98.5 \pm 9.3$ & $\begin{array}{c}152.5 \pm \\
6.9\end{array}$ & $94.6 \pm 0.6$ \\
\hline 19 & $-\mathrm{N}\left(\mathrm{CH}_{2} \mathrm{CH}_{2}\right)_{2} \mathrm{NCH}_{2} \mathrm{C}_{6} \mathrm{H}_{5}$ & $52.8 \pm 11.9$ & $101.6 \pm 7.2$ & $59.2 \pm 4.2$ & $\begin{array}{c}140.37 \pm \\
0.0\end{array}$ & $\begin{array}{c}155.1 \pm \\
6.2\end{array}$ & $111.2 \pm 2.2$ \\
\hline 20 & $-\mathrm{N}\left(\mathrm{CH}_{2} \mathrm{CH}_{2}\right)_{2} \mathrm{NC}_{6} \mathrm{H}_{4} \mathrm{~F}(o)$ & $82.5 \pm 11.9$ & $94.7 \pm 16.9$ & $66.4 \pm 2.6$ & $\begin{array}{c}119.9 \pm \\
9.0\end{array}$ & $\begin{array}{c}145.8 \pm \\
8.2\end{array}$ & $122.7 \pm 5.1$ \\
\hline 21 & $\begin{array}{l}-\mathrm{N}\left(\mathrm{CH}_{2} \mathrm{CH}_{2}\right)_{2} \\
\mathrm{NC}_{6} \mathrm{H}_{4} \mathrm{OCH}_{3}(o)\end{array}$ & $24.7 \pm 8.5$ & $39.5 \pm 11.2$ & $63.3 \pm 7.0$ & $\begin{array}{c}128.9 \pm \\
16.7\end{array}$ & $\begin{array}{c}165.3 \pm \\
15.9\end{array}$ & $\begin{array}{c}118.8 \pm \\
17.4\end{array}$ \\
\hline
\end{tabular}

(Continued) 


\begin{tabular}{|c|c|c|c|c|c|c|c|}
\hline \multirow{3}{*}{$\begin{array}{l}\text { Compd } \\
\text { SJ }\end{array}$} & \multirow{3}{*}{$\mathbf{R}$} & \multicolumn{6}{|c|}{ H1299 $^{a}$} \\
\hline & & \multicolumn{3}{|c|}{$\operatorname{SEAP}(\% \pm \mathrm{SD})^{b}$} & \multicolumn{3}{|c|}{ MTT $(\% \pm$ SD $)$} \\
\hline & & Wnt1 & $\mathbf{m} \mathbf{1}^{c}$ & $\mathrm{~m} 6$ & Wnt1 & m1 & m6 \\
\hline 22 & $\begin{array}{l}-\mathrm{N}\left(\mathrm{CH}_{2} \mathrm{CH}_{2}\right)_{2} \\
\mathrm{NC}_{6} \mathrm{H}_{4} \mathrm{OCH}_{3}(m)\end{array}$ & $47.1 \pm 0.6$ & $79.1 \pm 8.6$ & $63.9 \pm 6.8$ & $98.6 \pm 4.4$ & $\begin{array}{c}110.7 \pm \\
10.7\end{array}$ & $\begin{array}{c}102.1 \pm \\
11.4\end{array}$ \\
\hline 23 & $\begin{array}{l}-\mathrm{N}\left(\mathrm{CH}_{2} \mathrm{CH}_{2}\right)_{2} \mathrm{NCH} \\
\left(\mathrm{CH}_{2} \mathrm{CH}_{2}\right)_{2} \mathrm{NCH}_{3} \\
\end{array}$ & $49.2 \pm 22.4$ & $112.2 \pm 26.7$ & $55.6 \pm 14.2$ & $\begin{array}{c}110.5 \pm \\
3.2\end{array}$ & $\begin{array}{c}135.6 \pm \\
3.1 \\
\end{array}$ & $\begin{array}{c}103.9 \pm \\
12.1\end{array}$ \\
\hline 24 & $-\mathrm{N}\left(\mathrm{CH}_{2} \mathrm{CH}_{2}\right)_{2} \mathrm{C}\left(\mathrm{OCH}_{2}\right)_{2}$ & $54.8 \pm 19.0$ & $122.0 \pm 12.8$ & $65.4 \pm 4.7$ & $\begin{array}{c}103.1 \pm \\
1.9\end{array}$ & $\begin{array}{c}131.0 \pm \\
34.2\end{array}$ & $114.6 \pm 4.3$ \\
\hline 25 & $\begin{array}{l}-\mathrm{N}\left(\mathrm{CH}_{2} \mathrm{CH}_{2}\right)_{2} \mathrm{~N}(\mathrm{CO}) \mathrm{N} \\
\left(\mathrm{CH}_{2} \mathrm{CH}_{2}\right)_{2} \mathrm{CH}_{2}\end{array}$ & $65.7 \pm 27.6$ & $113.2 \pm 20.7$ & $63.5 \pm 4.4$ & $\begin{array}{c}98.2 \pm \\
14.9 \\
\end{array}$ & $\begin{array}{c}146.5 \pm \\
7.6\end{array}$ & $114.0 \pm 6.8$ \\
\hline 26 & $\begin{array}{l}-\mathrm{N}\left(\mathrm{CH}_{2} \mathrm{CH}_{2}\right)_{2} \mathrm{CH}\left(\mathrm{CH}_{2}\right)_{3} \\
\mathrm{CH}\left(\mathrm{CH}_{2} \mathrm{CH}_{2}\right)_{2} \mathrm{NH}\end{array}$ & $42.7 \pm 1.9$ & $99.6 \pm 22.7$ & $83.7 \pm 15.7$ & $88.3 \pm 8.5$ & $\begin{array}{c}127.6 \pm \\
0.4\end{array}$ & $98.4 \pm 5.2$ \\
\hline 27 & $-\mathrm{SCH}_{2} \mathrm{CH}_{2} \mathrm{OH}$ & $42.0 \pm 7.6$ & $96.8 \pm 14.3$ & $63.4 \pm 1.7$ & $\begin{array}{c}97.0 \pm \\
10.8\end{array}$ & $\begin{array}{c}127.4 \pm \\
12.9\end{array}$ & $79.1 \pm 9.3$ \\
\hline
\end{tabular}

${ }^{a}$ Non-small lung cancer cells H1299 were grown in RPMI 1640 media supplemented with $10 \%$ fetal bovine serum, 100 units $/ \mathrm{mL}$ penicillin and $100 \mathrm{mg} / \mathrm{mL}$ streptomycin in a humidified atmosphere with $5 \% \mathrm{CO}_{2}$ at $37^{\circ} \mathrm{C}$.

${ }^{\mathrm{b} S D}$, standard derivation; all experiments were independently performed at least three times.

'The G-quadruplex-forming sequences of WNT1 (wild-type), WNT1-m1, or WNT1-m6 (WNT1 mutations) were indicated.

formation of G-quadruplex structure at its promoter, the SEAP activity of wild-type, $\mathrm{m} 1$ and $\mathrm{m} 6$ mutants were next compared (Table 1). Among the tested compounds, only $\mathbf{S J 2 6}$ did not repress $\mathrm{m} 1$ and $\mathrm{m} 6$ mutants, suggesting that the observed repression in wild-type promoter is G-quadruplex structure-dependent. We tested the SEAP repressing activity and cytotoxicity using multiple doses of SJ26. Consistent with the screening results, SJ26 selectively repressed wild-type $W N T 1$ promoter activity and the repression is G-quadruplex dependent as it did not significantly affect the other two mutant promoters (Figure 3). It is interesting to note that SJ26 did not show significant cytotoxic activity at concentration up to $30 \mu \mathrm{M}$. In addition to the stable lines that we used in the screen (Figure 3A and 3B), we have also conducted the reporter assays using transient transfection method to introduce reporter constructs into H1299 cells. As shown in Figure 3C, SJ26 selectively repressed the wild-type promoter, further confirming that the observed WNT1repressing activity by $\mathbf{S J 2 6}$ was mediated through the formation of G-quadruplex structure formed at the WNTI promoter. It is also apparent that transient transfect method yielded better inhibitory results.

\section{Effect of SJ26 on the melting temperature of WNT1 G-quadruplex}

We have previously showed that an oligonucleotide carrying the G-rich sequence of WNT1 promoter was capable of forming a G-quadruplex structure $[19,20]$. To evaluate the effect of SJ26 to the G-quadruplex structure of WNT1 promoter, we applied circular dichroism (CD) to monitor the melting temperature (Tm) of WNT1 G-quadruplex. Oligonucleotide containing the G-quadruplex-forming sequences of WNT1 promoter $(-193$ to -167$)$ were synthesized and analyzed by CD spectormetry. The CD spectrum of WNT1 oligonucleotide displayed a positive band at $264 \mathrm{~nm}$ and a negative band at $240 \mathrm{~nm}$ together with a relative weak positive band at $292 \mathrm{~nm}$ in the presence of $5 \mathrm{mM} \mathrm{K}^{+}$(Figure 4A). The result is consistent with our previous observation that WNT1 oligonucleotide forms a mixed parallel/antiparallel folding pattern with at least two different G-quadruplex conformations [19, 20]. Addition of SJ26 did not greatly affect the overall $\mathrm{CD}$ spectrum of the WNT1 G-quadruplexes. The 265-nm CD band was then measured as a function of temperature to determine the Tm of WNTI G-quadruplexes in the presence of $\mathbf{S J 2 6}$. Here we used relatively low molar ratio of $\mathbf{S J 2 6}(3 \mu \mathrm{M})$ to $W N T 1$ DNA $(5 \mu \mathrm{M})$ in our analysis. High molar ratio of $\mathbf{S J 2 6}$ was not used because we consider that high molar ratio of SJ26 relative to its target DNA is not the pharmacologically equivalent concentration. We found that the Tm of WNT1 G-quadruplexes was elevated from 54.2 to $57.7^{\circ} \mathrm{C}$ in the presence of $3 \mu \mathrm{M}$ SJ26, suggesting that it could thermally stabilize the WNT1 G-quadruplexes (Figure 4B).

\section{Effect of SJ26 represses WNT1 expression and reduces the migration activity of $\mathrm{H1299}$ cells}

The effect of SJ26 on WNT1 expression was further analyzed. As shown in Figure 5, real time RT-PCR analysis 


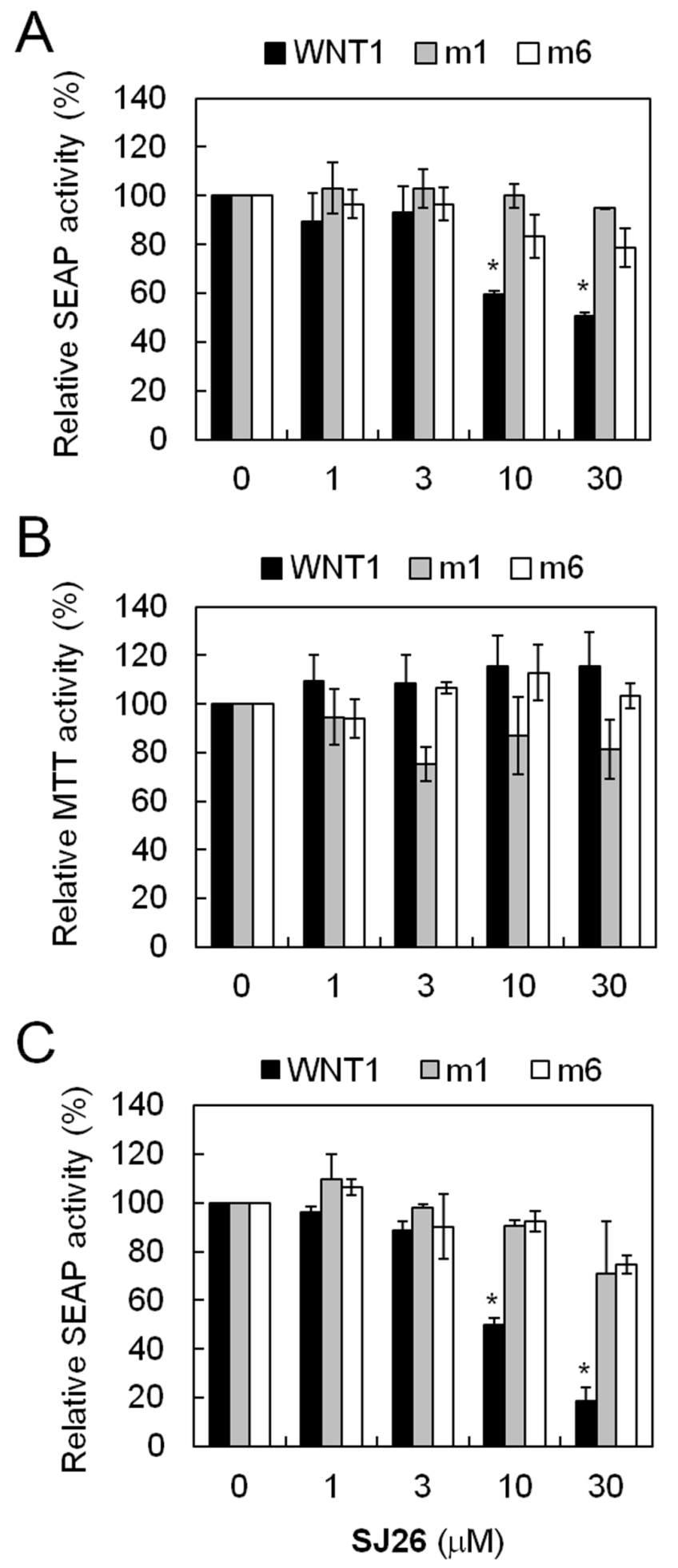

Figure 3: SJ26 repressed WNT1 expression in a G-quadruplex dependent manner. A. Suppression of $W N T 1$ expression by SJ26 using reporter-harboring stable cell lines. The H1299 cells harboring wild-type, WNT1-m1, and WNT1-m6 reporters were incubated with the indicated concentrations of $\mathbf{S J 2 6}$ for $24 \mathrm{~h}$. The phosphatase activities were then analyzed using the activity of DMSO-treated cells as $100 \%$. B. Cytotoxic effects of SJ26. About $2 \times 10^{4} \mathrm{H} 1299$ cells were seeded in 96-well plates and incubated with $\mathbf{S J 2 6}$ at various concentrations for $24 \mathrm{~h}$. Cell growth was then determined using the MTT assay. The values are obtained from three experiments using the values of untreated cells as 100\%. C. Suppression of WNT1 expression by SJ26 using transient-transfected reporter assays. Reporter plasmid constructs carrying wild-type, WNT1-m1, and WNT1-m6 promoters were transfected into H1299 cells using lipofecamin 2000. The transfected cells were incubated with the indicated concentrations of $\mathbf{S J 2 6}$ for $24 \mathrm{~h}$. The phosphatase activities were then analyzed using the activity of DMSO-treated cells as $100 \%$. Asterisks indicate $p<0.05$. 
showed that the WNT1 mRNA level was significantly decreased in cells that were treated with SJ26 (Figure 5A). Moreover, immunoblotting analysis of the SJ26-treated lung cancer H1299 cells showed that the Wnt1 protein levels were greatly decreased by $\mathbf{S J 2 6}$ treatment at a dose as low as $1 \mu \mathrm{M}$ (Figure 5B). These results indicate that SJ26 could stabilize G-quadruplex structure and reduce the expression of WNT1. It is also interesting to note that although it requires $\sim 10 \mu \mathrm{M}$ to observed the repressing effect in our cell-based SEAP reporter system, SJ26 at concentration as low as $1 \mu \mathrm{M}$ was able to suppress the endogenous WNT1 expression. Although the reason is not clear to us, the apparent differences might be due to the difference of sensitivity in these assay systems. The downstream effect of Wnt1-mediated signaling pathway by SJ26 was also analyzed. Immunoblotting analysis showed that the $\beta$-catenin levels were decreased by SJ26 (Figure 5B). Since the Wnt1-mediated signaling pathway was shown to have an important role in cancer migration and invasion, the cellular effects of suppressing WNT1 expression by SJ26 were analyzed. The migration activity of SJ26-treated cells was first evaluated using scratch assays. As shown in Figure 5C, the healing activity of H1299 cells was decreased by SJ26 in a dose dependent manner. The anti-proliferation efficacy of SJ26 was also determined. We found SJ26 did not affect the proliferation of H1299 cells, suggesting the observed healing-inhibitory effect was not due to inhibition of proliferation. To show that the anti-healing effect of SJ26 was through suppression of Wnt1-mediated pathway, we
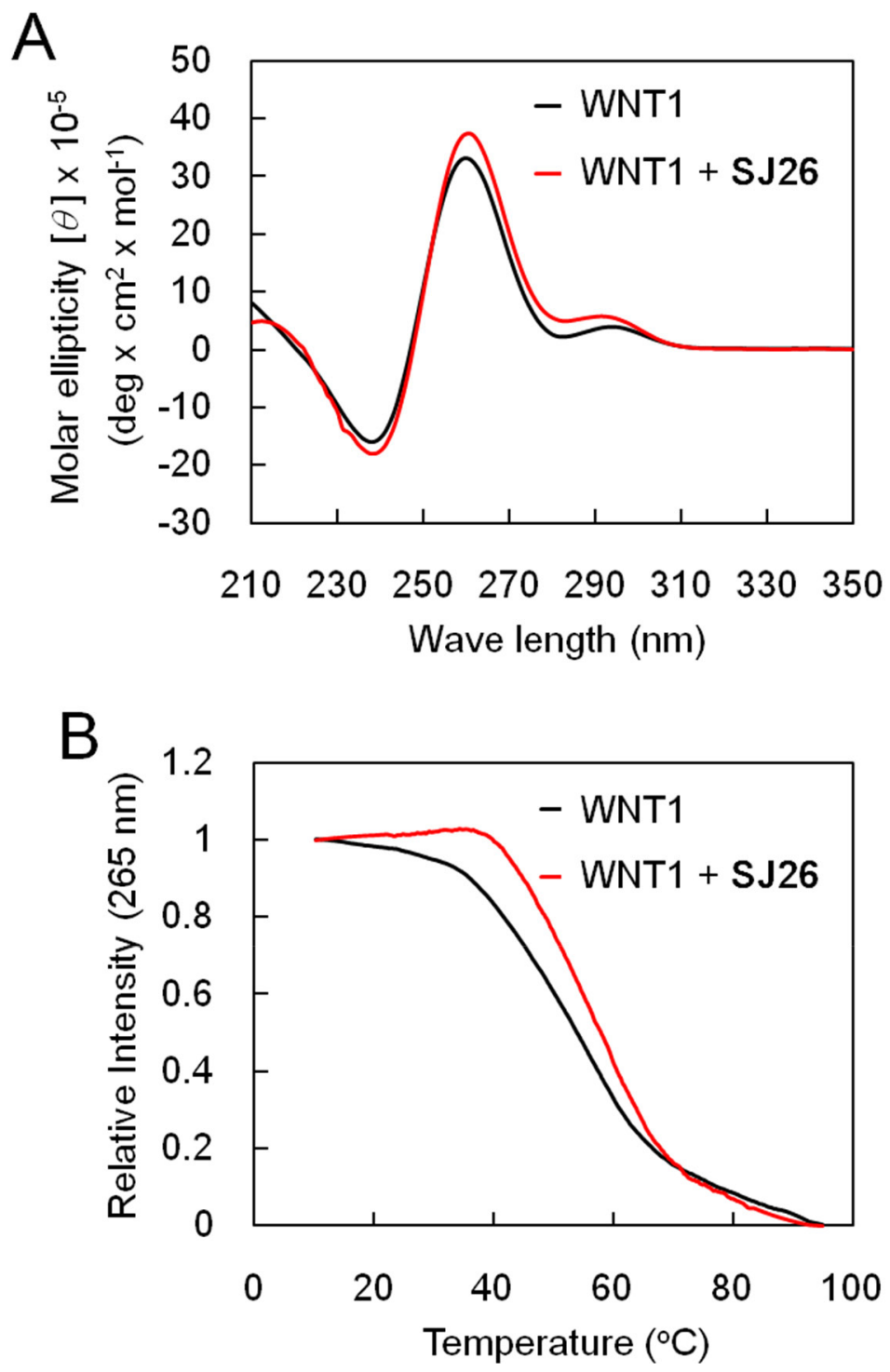

Figure 4: SJ26 enhances the melting temperature of $\boldsymbol{W N T 1}$ G-quadruplex. A. CD spectra of the $W N T 1$ G-rich sequence. The CD spectra of $100 \mu \mathrm{M}$ WNT1 (5'-GGGGGCCACCGGGCAGGGGGCGGGGG-3') oligonucleotide in the presence of $5 \mathrm{mM}$ KCl were recorded over the spectral range of 210-350 nm. B. Temperature-dependent CD signals at $265 \mathrm{~nm}$ of $5 \mu \mathrm{M} \mathrm{WNT1}$ quadruplex and on interaction with $3 \mu \mathrm{M}$ SJ26 were measured, respectively. 
overexpressed WNT1 in SJ26-treated cells. We expected that expressing of excess amount of Wnt1 should reverse the anti-healing effect by SJ26. Plasmid construct harboring WNT1 under the control of a CMV promoter was transfected into H1299 cells. Indeed, the scratch analysis also indicated that the inhibitory effect of SJ26 was reversed in WNT1-overexpressing cells (Figure 5D). The results indicate that the migration inhibitory effect of SJ26 was mediated through suppressing the Wnt1mediated signaling pathway.
A

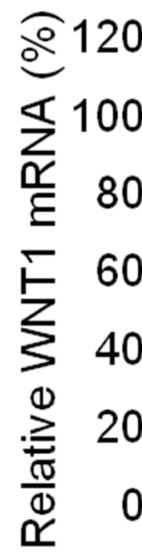

B

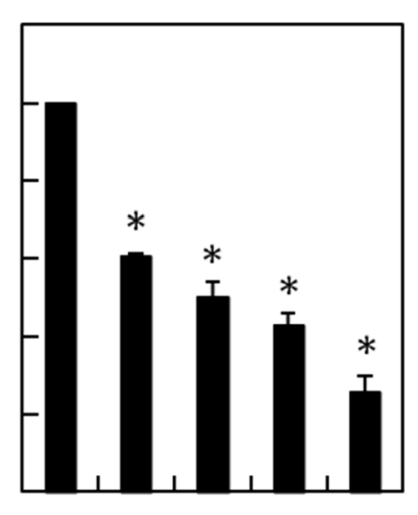

$\begin{array}{lllll}0 & 1 & 3 & 10 & 30\end{array}$

$\mathrm{SJ} 26(\mu \mathrm{M})$

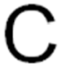

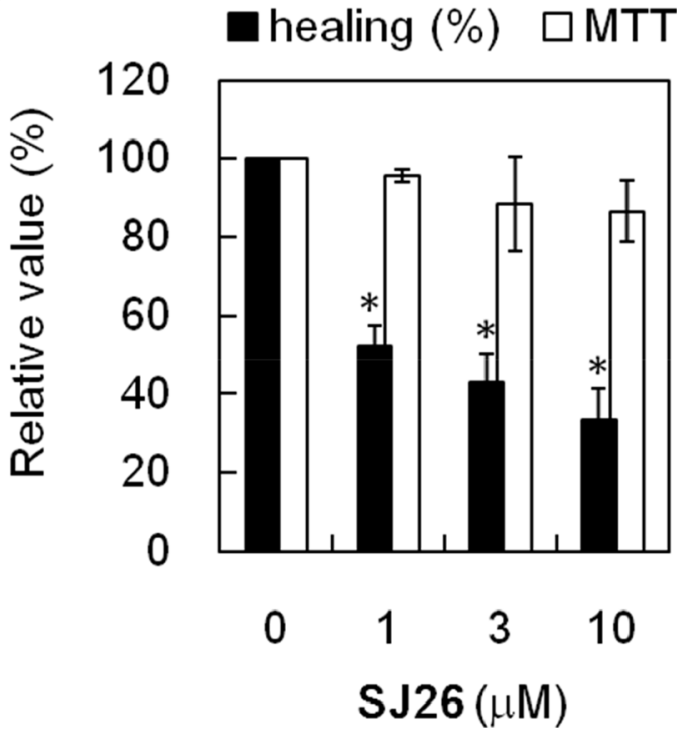

$D$

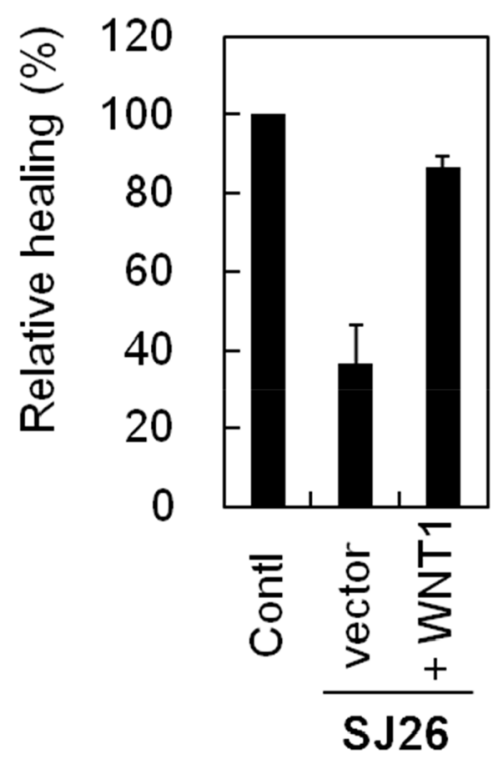

Figure 5: SJ26 repressed WNT1 expression and reduced the migration activity of H1299 cells. A. SJ26 reduced the $W N T 1$ mRNA level. The H1299 cells was incubated with 1, 3, 10, or $30 \mu \mathrm{M} \mathrm{SJ26}$ for $24 \mathrm{~h}$ and then subjected to quantitative RT-PCR analysis. The GAPDH expression level was used as an internal control. The mRNA level of WNT1 expression in untreated H1299 cells was defined as $100 \%$. Results were obtained from the average of three independent experiments. Asterisks indicate $p<0.05$. B. SJ26 reduced the Wnt 1 protein and its down strean mediator $\beta$-catenin levels. H1299 cells were incubated with 1, 3, 10, or $30 \mu \mathrm{M} \mathrm{SJ26} \mathrm{for} 24 \mathrm{~h}$. Total cell extracts were prepared, and immunoblotting analysis was conducted using antibodies against Wnt1, $\beta$-catenin, or $\alpha$-tubulin. C. SJ26 reduced the healing activity of H1299 cells. H1299 cells were incubated with $10 \mu \mathrm{M}$ DMSO or 1, 3, or $10 \mu \mathrm{M} \mathrm{SJ26}$ for 48 h, and then the treated cells were subjected for scratch assays. Relative migration rates of $\mathrm{H} 1299$ cells were determined by migration distance over the time. Cell growth was also determined using the MTT assay. The value of migration rate or cell growth in DMSO-treated cells was defined as $100 \%$. Asterisks indicate $p<0.05$. D. WNT1-overexpression reversed the healing-inhibitory activity of SJ26. The relative healing rates were determined in $10 \mu \mathrm{M}$ SJ26-treated cells that overexpressing WNT1. The relative healing rate in DMSO-treated H1299 cells was defined as $100 \%$. 


\section{Suppression of Wnt1-mediated cell migration by SJ26 was not limited to H1299 cells}

To test the effects of WNT1 expression and migration upon SJ26 treatments on other cancer cell lines, the MCF7 (breast cancer) and Hep2B 2.17 (liver cancer) cells were also tested. We found $\mathbf{S J 2 6}$ effectively repressed the expression of $W N T 1$ and $\beta$-catenin in these cells (Figure 6A). The migration activity was next evaluated using trans-well assays. As shown in Figure 6B, SJ26 effectively inhibited the migration activity of
H1299 cells. Both the migration activities of MCF7 and Hep3B cells were also inhibited by $\mathbf{S J 2 6}$, although not as effective as in H1299 cells. It was noted that the level of Wnt1/ $\beta$-catenin repression by $\mathbf{S J 2 6}$ correlated with their reduction in migration activity. Thus, the cellular context in different cell types might also have a role in modulating the repressing effects of SJ26. Nevertheless, the correlation between $\mathrm{Wnt} 1 / \beta$-catenin repressing and migration inhibition by $\mathbf{S J 2 6}$ provides strong indication that $\mathbf{S J 2 6}$ inhibit the migration activity of cancer cells through repressing the expression of WNT1.
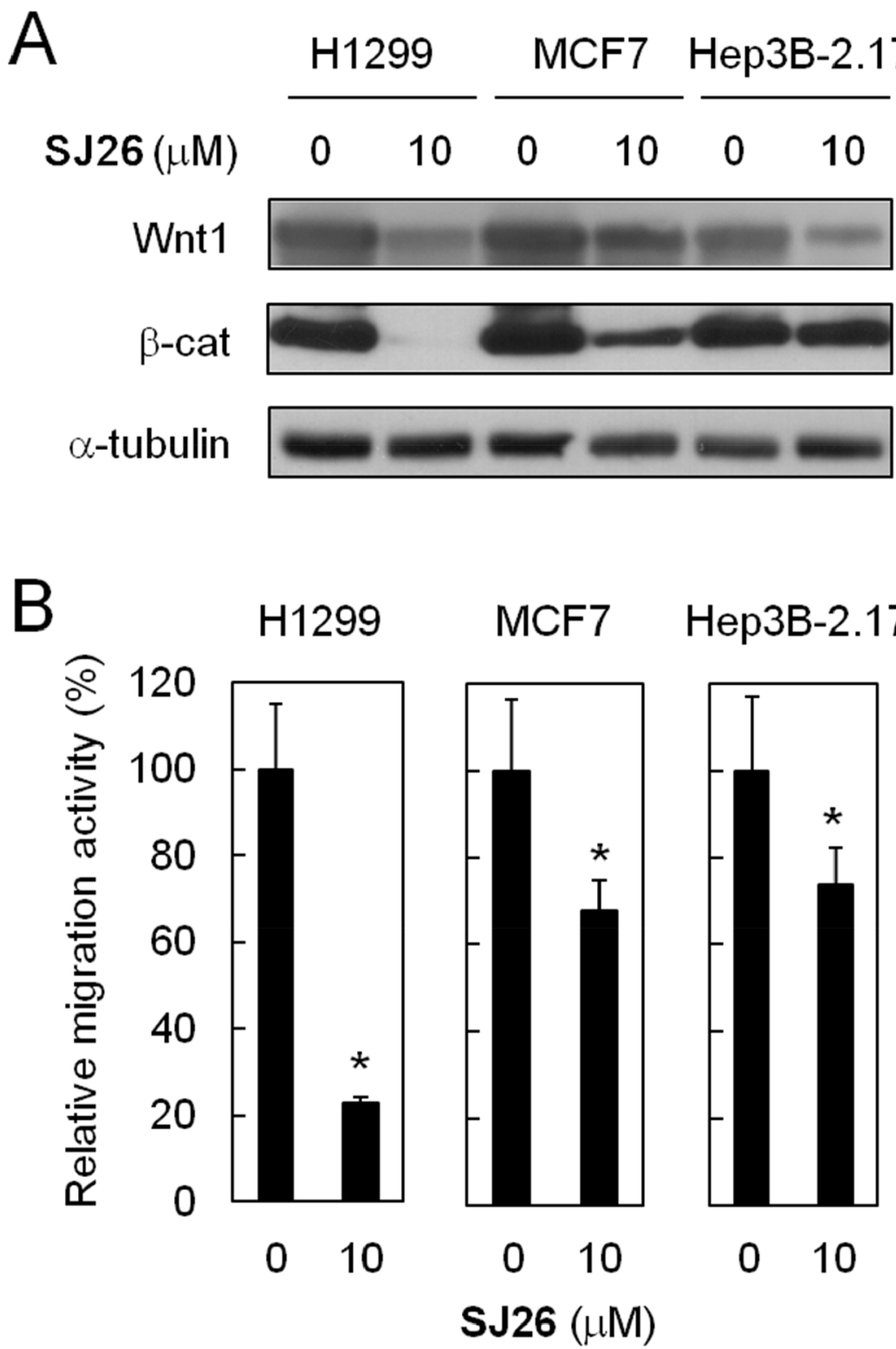

Figure 6: SJ26 suppressed cell migration in H1299, MCF7 and Hep3B 2.17 cells. A. SJ26 suppressed Wnt1/B-cateninsignaling pathway in H1299, MCF7 and Hep3B 2.17 cells. Cells were treated with $10 \mu$ M SJ26 and the total cell extracts were prepared. Immunoblotting analysis was conducted using antibodies against Wnt1, $\beta$-catenin, or $\alpha$-tubulin. B. H1299, MCF7 or Hep3B 2.17 cells were incubated with $10 \mu \mathrm{M}$ of $\mathbf{S J 2 6}$ and were subjected to trans-well assay analysis. The extent of cell migration across the wells was recorded after 6 hours. The value of migration rate in DMSO-treated cells was defined as 1. Asterisks indicate $p<0.05$. 


\section{DISCUSSION}

Aberrant activation of the Wnt pathway is implicated in driving the formation of various human cancers. Many cancers show evidence of inappropriate activation of the Wnt pathway, including raised levels of $\beta$-catenin $[44,45]$. Moreover, defective Wnt signaling might also play a role in the generation and maintenance of cancer stem cells [46]. Thus, Wnt signaling plays a pivotal role in cancer, and compounds that dampen Wnt pathway activity could provide useful molecular targeted therapeutics for the treatment of cancers [11, 47-49]. An assortment of small molecule inhibitors has been identified that target the mediators of the Wnt signaling pathway. For example, compound ICG-001 was shown to block the interaction between $\beta$-catenin and the transcriptional coactivator protein CREB binding protein (CBP) [50]. Recently, several new compounds that target tankyrase activity were also developed such as NVP-TNKS656 [51], G007-LK [52], and LGK974 [53]. Moreover, a small-molecule porcupine (PORCN) acyltransferase inhibitor, IWP-2, was found to inhibit the secretion of functional WNT ligands [13]. Here we identify repressors that inhibit WNT1 expression through stabilizing the G-quadruplex structure formed at its promoter. The 6-substituted 9-chloro-11H-indeno[1,2-c]quinolin-11-one derivatives are capable of inhibiting the $W N T$-signaling pathway through suppressing the expression of WNT1. Thus, our results support a unique approach to inhibit WNT-mediated signaling pathway through suppression of WNT1 expression. The identified target compounds should have potential to be further developed into drugs to treat Wnt-related diseases.

The cell-based reporter assay we established enables efficient monitoring and analyzing WNT1 expression. In our screen system, we have also added WNT1-m1 and -m6 mutation constructs to enable the determination of whether the repression requires G-quadruplex structure formation. Thus, this cell-based system could be applied to gauge the expression of WNT1 in a G-quadruplex structure dependent manner. Using the reporter system, we have successfully identified SJ26. SJ26 effectively represses the expression of WNT1, its downstream signaling pathway, and the migration activity of cancer cells. Importantly, the WNT1 inhibitory effect mediated by SJ26 appears to be selective and specific as it does not affect the general proliferation property of cells at concentrations as high as $30 \mu \mathrm{M}$. It is also interesting to note that $\mathbf{S J 2 6}$ only moderately elevates the melting temperature of a G-quadruplex structure formed by WNT1 promoter sequences. Although moderate, the melting-temperature elevation is sufficient to repress WNT1 expression and inhibit its downstream signaling pathway. Thus, the results suggest that our reporter assay could identify G-quadruplex stabilizers with high sensitivity.
Azafluorenone compounds show diverse pharmacological activities. For example, they have been reported to have antifungal, antimicrobial, and antimalarial activities [54-56]. They were also shown to have cytotoxic properties to induce cancer cells into apoptosis [57-59]. Moreover, an arylindenopyrimidine was shown to be a potent dual A2A/A1 receptor antagonist that might have the potential for the treatment of neurodegenerative disorder such as Parkinson's disease [60]. Our results in stabilization of the G-quadruplex structure point to a new pharmacological direction that azafluorenone compounds could also target to specific DNA structure. Much work yet needs to be done to fully understand the precise mechanisms of these series compounds. In conclusion, we demonstrated that SJ26 play a novel anticancer mechanism, and it has the potential to be further developed into anti-cancer drugs that targets the migration activity of cancer cells.

\section{MATERIALS AND METHODS}

\section{Chemicals and test derivatives}

In this study, we systematically synthesized tetracyclic and heterocyclic pharmacophores by introducing a series of side chains linked to the 9-chloro$11 H$-indeno[1,2-c]quinolin-11-one moiety. The synthesis of 3,6-bis(1-methyl-4-vinylpyridinium)carbazole diiodide (BMVC) has been described previously [61]. General chemicals used in this study were purchased from (Sigma-Aldrich). Cell lines (human lung cancer H1299; human breast cancer MCF7; human liver cancer Hep3B 2.17) were obtained from the Bioresource Collection and Research Center in Taiwan. All reactions were monitored by TLC (silica gel $60 \mathrm{~F}_{254}$ ). ${ }^{1} \mathrm{H}$ NMR and ${ }^{13} \mathrm{C}$ NMR were measured on Varian GEMINI-300 (300 MHz) or Agilent $400 \mathrm{MR}$ DD2 (400 MHz); $\delta$ values are in ppm relative to TMS as an internal standard. Multiplicities are recorded as s (singlet), d (doublet), $\mathrm{t}$ (triplet), q (quartet), quin (quintuplet), dd (doublet of doublets), dt (triplet of doublets), td (doublet of triplets), $\mathrm{m}$ (multiplet), and br (broadened). Mass spectral analyses were conducted using high resolution electron impact ionization (HREI, Finnigan MAT MAT-95XL) in the Instrumentation Center of National Tsing-Hua University, Hsinchu, Taiwan. Melting points of synthetic compounds were determined with a Büchi B-545 melting point apparatus. The purity of all compounds was analyzed on a $\mathrm{C} 18$ reverse-phase column (XBridge BEH Shield RP18 Column, 130 , $5 \mu \mathrm{m}, 4.6 \mathrm{~mm}$ X $250 \mathrm{~mm}$, Waters) by HPLC (model L-2000, HITACHI) with UV detection (model L-2400, HITACHI). Compound was dissolved in $\mathrm{MeOH}$; the mobile phase was water and $\mathrm{MeOH}$. A preliminary evaluation of the UV spectra was carried out by spectrophotometric analysis to determine the value of $\lambda$ max for each compound. The purities of the synthetic 
compounds for biological evaluation were greater than 95\%. Reagents and solvents were purchased from Merck and Sigma Aldrich and used without further purification. Typical experiments illustrating the general procedures for the preparation of the compounds are described below.

\section{Cell-based assay for monitoring $W N T 1$ expression}

The WNT1 promoter ranging from -600 to 201 relative to the transcription starting site was PCRamplified from H1299 genomic DNA and cloned upstream to a secreted alkaline phosphatase (SEAP) reporter gene to generate pWNT1-SEAP [19]. This DNA fragment contains the G-quadruplex forming sequences and the cis-regulatory elements of WNT1 transcription. To construct a mutant that fails to form G-quadruplex structure, plasmid pWNT1-SEAP was used as the template for mutagenesis using Pfu DNA polymerase (Stratagene). The resulting mutations were verified by DNA sequencing of the plasmids. These plasmids were introduced into cancer cell line H1299 and the stable cell lines harboring these plasmids were then isolated. Compared to their parental H1299 cell, no apparent change in the morphology or growth rate was observed in these stable lines.

\section{SEAP assay [62]}

Secreted alkaline phosphatase was used as the reporter gene to monitor the transcriptional activity of WNT1. About $2 \times 10^{4}$ each of cells were grown in 96-well plates and incubated at $37^{\circ} \mathrm{C}$ for $24 \mathrm{~h}$ and then changed with fresh media. Indicated amounts of drugs were added and then incubated for another $24 \mathrm{~h}$. The culture media were collected and heated at $65^{\circ} \mathrm{C}$ for $10 \mathrm{~min}$ to inactivate heat-labile phosphatases. To assay phosphatase activity. an equal amount of SEAP buffer (2 M diethanolamine, $1 \mathrm{mM} \mathrm{MgCl}_{2}$, and $20 \mathrm{mM}$ L-homoarginine) was added to the media, and $p$-nitrophenylphosphate was added to a final concentration of $12 \mathrm{mM}$. Absorptions at $405 \mathrm{~nm}$ were taken (BECKMAN BIOMEK 3000), and the rate of absorption increase was determined.

\section{MTT (3-(4,5-dimethylthiazol-2-yl)-2, 5-diphenyltetrazolium bromide) assay}

Cells were first grown in 96-well plates $(\sim 2000$ cells per well) in the presence of $5 \% \mathrm{CO}_{2}$ at $37^{\circ} \mathrm{C}$. To examine the cytotoxic effect of the tested compounds, cells were incubated with different concentrations of compounds for $24 \mathrm{~h}$. The cytotoxicity was then determined by adding MTT solution to cells to a final concentration of $0.45 \mathrm{mg} / \mathrm{ml}$ and incubated at $37^{\circ} \mathrm{C}$ for 1 hour. The resulting formazan crystals was dissolved and analysed spectrophotometrically at the absorbance of $570 \mathrm{~nm}$.

\section{DNA preparation}

All oligonucleotides were purchased from Bio Basic (Ontario, Canada) and used without further purification. DNA samples were prepared by dissolving oligonucleotides in $10 \mathrm{mM}$ Tris- $\mathrm{HCl}(\mathrm{pH}$ 7.5). DNA concentrations were determined using a UV-visible absorption nanophotometer (Implen). $\mathrm{KCl}$ at $5 \mathrm{mM}$ was added to the DNA samples $70 \mathrm{~min}$ before experiments. For SJ26 treatments, the DNA samples were incubated with SJ26 for $30 \mathrm{~min}$ before experiments.

\section{Circular dichroism (CD) spectra and melting temperature}

The CD spectra were recorded using a spectropolarimeter (J-815, Jasco, Japan) with a bandwidth of $2 \mathrm{~nm}$ at a scan speed of $50 \mathrm{~nm} / \mathrm{min}$ and a step resolution of $0.2 \mathrm{~nm}$ under $\mathrm{N}_{2}$ over the spectral range of 210-350 $\mathrm{nm}$ to monitor the $\mathrm{G} 4$ structures. Thermal melting curves were recorded by a Peltier thermal coupler chamber (PFD$425 \mathrm{~S} / 15$, Jasco) and the molar ellipticity was monitored at $265 \mathrm{~nm}$ between 10 and $100^{\circ} \mathrm{C}$ with a temperature ramping rate of $1^{\circ} \mathrm{C} / \mathrm{min}$ rate. The melting temperature $(T m)$ was measured from the first differential of the melting curve.

\section{Quantification of WNT1 RNA}

The real-time quantitative RT-PCR was also used to determine the mRNA of WNT1. Cells were treated with SJ26 for 1 day and then subjected to RT-PCR analysis. Total RNA was isolated using TRIzol reagent (Sigma) and reverse-transcribed by random hexamers using cDNA reverse transcription kit (Applied Biosystem). The reverse-transcribed products were then analyzed using Cyber Green I system (FastStart Universal SYBR Green Master, Roche Applied Science). Primers used for PCR reactions were: WNT1 (forward primer 5'-CTGTCCTGCCTCCTCATC-3' and reverse primer 5' -GGACCCAGCACAATAAATAGTT-3'); GAPDH (forward primer 5'-TAACTCTGGTAAAGTGGATA-3' and reverse primer 5'-AAGATGGTGATGGGATTT-3'). The parameter $\mathrm{Ct}$ is defined as the fractional cycle number at which the fluorescence is generated by the Cyber green I system. Quantifications were first determined by normalizing the $\mathrm{Ct}$ values of the tested mRNA with the $\mathrm{Ct}$ of $G A P D H$. The relative values were then obtained using no drug treatment as $100 \%$. Quantification results were obtained from three independent experiments.

\section{Immunoblotting analysis}

The SJ26-treated H1299 cells were washed twice with phosphate-buffered saline (PBS) and lysed using radioimmune precipitation assay buffer (10 mM Tris$\mathrm{HCl}$ (pH 7.4), 150 mM NaCl, 5 mM EDTA, 1\% Triton $\mathrm{X}-100,100 \mu \mathrm{M}$ phenylmethylsulfonyl fluoride, $1 \mathrm{mg} / \mathrm{ml}$ 
leupeptin, $1 \mathrm{mg} / \mathrm{ml}$ aprotinin, and $25 \mathrm{mM}$ dithiothreitol). Equal amount of total proteins were separated on SDSPAGE gels and transferred to nitrocellulose membranes. Antibodies against Wnt1 (1:1000 dilution, Spring, REF E3960), $\beta$-catenin (1:1000 dilution, GeneTex, GTX61089), and $\alpha$-tubulin (1:5000 dilution, Millipore, MAB374) were used as the primary antibodies. Horseradish peroxidase-conjugated anti-mouse IgG or anti-rabbit IgG (Amersham Biosciences) were used as the secondary antibodies. Blots were visualized using enhanced chemiluminescence system (PerkinElmer Life Sciences).

\section{Scratch assay}

Cells were treated with compound $\mathbf{S J 2 6}$ for 1 day and subjected to scratch assay. The drug treated cells were plated and scratched with a pipette tip to generate a cellfree zone. Cells were then incubated at $1 \%$ serum culture medium to avoid further cell proliferation. Migration of cells toward the cell-free zone was monitored after $24 \mathrm{~h}$ using a Leica DFC 420c camera (Leica Microsystems), and the migration rates were determined. The relative healing activities were obtained using the value of solvent control as $100 \%$.

\section{Trans-well assay}

About $2 \times 10^{5}$ of the drug-treated cells were grown in the inner chamber of Millicell Hanging Cell Culture Insert (pore size $8.0 \mu \mathrm{m}$, Merck Millipore) in a serumfree medium and with $10 \%$ serum medium in the outer chamber. The cells were incubated at $37^{\circ} \mathrm{C}$ for $6 \mathrm{~h}$ to allow the migration toward the outer side of the inner chamber. Cells were fixed with $4 \%$ paraformaldehyde for $2 \mathrm{~min}$, and then permeabilized with methanol for $20 \mathrm{~min}$. The cells on the inner layer were softly removed with a cotton swab, and the adherent cells on outer surface were stained with $0.3 \%$ crystal violet dye for $15 \mathrm{~min}$ and then counted. The relative migration activities were obtained using the value of solvent control as $100 \%$.

\section{Statistical analysis}

Student's $t$-test was applied to assess whether the means of two groups are statistically different from each other. Here, we consider $P<0.05$ as significant.

\section{Abbreviations}

WNT1, wingless-type MMTV integration site family, member 1; CD, circular dichroism; Tm, melting temperature; SEAP, secreted alkaline phosphatase; SARs, structure-activity relationships; CPT, Camptothecin; Topo, topoisomerase; BMVC, 3,6-bis(1-methyl-4- vinylpyridinium)carbazole diiodide; CD, circular dichroism; H1299, human non-small cell lung carcinoma cell; HRMS, high resolution mass; PBS, phosphatebuffered saline; DMSO, dimethyl sulfoxide; THF, tetrahydrofuran; TEA, triethylamine.

\section{ACKNOWLEDGMENTS}

We thank Dr. Fong-Chun Huang for his kind support on establishing the assay system. We also thank the Biophysical Instrumentation Laboratory at the Institute of Biological Chemistry, Academia Sinica, Taiwan for assistance in $\mathrm{CD}$ analysis. The present study was also supported by the Ministry of Science and Technology and Taipei Medical University grants (NSC 101-2113-M-016-001, TMU102AE1-B32 and TMUTOP-103003 to H.S. Huang and NSC 101-2311-B-002-020-MY3 to J.J. Lin.)

\section{CONFLICTS OF INTEREST}

The authors disclose no potential conflicts of interest.

\section{Author contributions}

Lien-Cheng Chang established the biological assay system and conducted the analyses; Tsung-Chih Chen, Chun-Liang Chen, Shiag-Jiun Chen, Chia-Chung Lee, synthesized and characterized the compounds used in this study; Shih-Hsiung Wu, Yun Yen, Jing-Jer Lin, and HsuShan Huang designed the research, analyzed results and writing the manuscript. These authors contributed equally to this work.

\section{REFERENCES}

1. Wan L, Pantel K and Kang Y. Tumor metastasis: moving new biological insights into the clinic. Nature Med. 2013; 19:1450-1464.

2. Clevers $H$ and Nusse $R$. Wnt/ $\beta$-catenin signaling and disease. Cell. 2012; 149:1192-1205.

3. Wong SCC, Lo SFE, Lee KC, Yam JWP, Chan JKC and Hsiao WLW. Expression of frizzled-related protein and Wnt-signalling molecules in invasive human breast tumours. J Pathol. 2002; 196:145-153.

4. Kim YC, Clark RJ, Ranheim EA and Alexander CM. Wnt1 expression induces short-range and long-range cell recruitments that modify mammary tumor development and are not induced by a cell-autonomous beta-catenin effector. Cancer Res. 2008; 68:10145-10153.

5. Tao W, Pennica D, Xu L, Kalejta RF and Levine AJ. Wrch-1, a novel member of the Rho gene family that is regulated by Wnt-1. Genes Dev. 2001; 15:1796-1807. 
6. He W, Tan RJ, Li Y, Wang D, Nie J, Hou FF and Liu Y. Matrix metalloproteinase-7 as a surrogate marker predicts renal Wnt/ $\beta$-catenin activity in CKD. J Am Soc Nephrol. 2012; 23:294-304.

7. Xu X, Sun PL, Li JZ, Jheon S, Lee CT and Chung JH. Aberrant Wnt1/ $\beta$-catenin expression is an independent poor prognostic marker of non-small cell lung cancer after surgery. J Thorac Oncol. 2011; 6:716-724.

8. Chen G, Shukeir N, Potti A, Sircar K, Aprikian A, Goltzman D and Rabbani SA. Up-regulation of Wnt1 and $\beta$-catenin production in patients with advanced metastatic prostate carcinoma: potential pathogenetic and prognostic implications. Cancer. 2004; 101:1345-1356.

9. Nakashima T, Liu D, Nakano J, Ishikawa S, Yokomise H, Ueno M, Kadota K and Huang CL. Wnt1 overexpression associated with tumor proliferation and a poor prognosis in non-small cell lung cancer patients. Oncol Rep. 2008; 19:203-209.

10. Polakis P. Drugging Wnt signalling in cancer. EMBO J. 2012; 31:2737-2746.

11. Anastas JN and Moon RT. WNT signalling pathways as therapeutic targets in cancer. Nat Rev Cancer. 2013; 13:11-26.

12. Lepourcelet M, Chen Y-NP, France DS, Wang H, Crews P, Petersen F, Bruseo C, Wood AW and Shivdasani RA. Small-molecule antagonists of the oncogenic Tcf/ $\beta$-catenin protein complex. Cancer Cell. 2004; 5:91-102.

13. Chen B, Dodge ME, Tang W, Lu J, Ma Z, Fan C-W, Wei S, Hao W, Kilgore J, Williams NS, Roth MG, Amatruda JF, Chen C and Lum L. Small molecule-mediated disruption of Wnt-dependent signaling in tissue regeneration and cancer. Nat Chem Biol. 2009; 5:100-107.

14. Ewan K, Pajak B, Stubbs M, Todd H, Barbeau O, Quevedo C, Botfield H, Young R, Ruddle R, Samuel L, Battersby A, Raynaud F, Allen N, Wilson S, Latinkic B, Workman P, et al. A useful approach to identify novel small-molecule inhibitors of Wnt-dependent transcription. Cancer Res. 2010; 70:5963-5973.

15. Sack U, Walther W, Scudiero D, Selby M, Aumann J, Lemos C, Fichtner I, Schlag PM, Shoemaker RH and Stein U. S100A4-induced cell motility and metastasis is restricted by the Wnt/ $\beta$-catenin pathway inhibitor calcimycin in colon cancer cells. Mol Biol Cell. 2011; 22:3344-3354.

16. Huang SM, Mishina YM, Liu S, Cheung A, Stegmeier F, Michaud GA, Charlat O, Wiellette E, Zhang Y, Wiessner S, Hild M, Shi X, Wilson CJ, Mickanin C, Myer V, Fazal A, et al. Tankyrase inhibition stabilizes axin and antagonizes Wnt signalling. Nature. 2009; 461:614-620.

17. Wei W, Chua MS, Grepper S and So SK. Blockade of Wnt-1 signaling leads to anti-tumor effects in hepatocellular carcinoma cells. Mol Cancer. 2009; 8:76.

18. He B, Reguart N, You L, Mazieres J, Xu Z, Lee AY, Mikami I, McCormick F and Jablons DM. Blockade of Wnt-1 signaling induces apoptosis in human colorectal cancer cells containing downstream mutations. Oncogene. 2005; 24:3054-3058.

19. Wang J-M, Huang F-C, Kuo MH-J, Wang Z-F, Tseng T-Y, Chang L-C, Yen S-J, Chang T-C and Lin J-J. Inhibition of cancer cell migration and invasion through suppressing the Wnt1-mediating signal pathway by G-quadruplex structure stabilizers. J Biol Chem. 2014; 289:14612-14623.

20. Kuo MH-J, Wang Z-F, Tseng T-Y, Li M-H, Hsu S-TD, Lin J-J and Chang T-C. The conformational transition of a hairpin structure to G-quadruplex within the WNT1 gene promoter. J Am Chem Soc. 2015; 137:210-218.

21. Sun D, Thompson B, Cathers BE, Salazar M, Kerwin SM, Trent JO, Jenkins TC, Neidle S and Hurley LH. Inhibition of human telomerase by a G-quadruple-interactive compound. J Med Chem. 1997; 40:2113-2128.

22. Huang H-S, Chou C-L, Guo C-L, Yuan C-L, Lu Y-C, Shieh F-Y and Lin J-J. Human telomerase inhibition and cytotoxicity of regioisomeric disubstituted amidoanthraquinones and aminoanthraquinones. Bioorg Med Chem. 2005; 13:1435-1444.

23. Huang H-S, Chen I-B, Chen T-C, Huang K-F, Lu W-C, Shieh F-Y, Huang Y-Y, Huang F-C and Lin J-J. Synthesis and human telomerase inhibition of a series of regioisomeric disubstituted amidoanthraquinones. Chem Pharm Bull. 2007; 55:284-292.

24. Huang H-S, Huang K-F, Li C-L, Huang Y-Y, Chiang Y-H, Huang F-C and Lin J-J. Synthesis, human telomerase inhibition and anti-proliferative studies of a series of 2,7-bissubstituted amido-anthraquinone derivatives. Bioorg Med Chem. 2008; 16:6976-6986.

25. Huang H-S, Chen T-C, Chen R-H, Huang K-F, Huang F-C, Jhan J-R, Chen C-L, Lee C-C, Lo Y and Lin J-J. Synthesis, cytotoxicity and human telomerase inhibition activities of a series of 1,2-heteroannelated anthraquinones and anthra[1,2-d]imidazole-6,11-dione homologues. Bioorg Med Chem. 2009; 17:7418-7428.

26. Lee C-C, Huang K-F, Lin P-Y, Huang F-C, Chen C-L, Chen T-C, Guh J-H, Lin J-J and Huang H-S. Synthesis, antiproliferative activities and telomerase inhibition evaluation of novel asymmetrical 1,2-disubstituted amidoanthraquinone derivatives. Eur J Med Chem. 2012; 47:323-336.

27. Lee C-C, Hsu J-J, Huang F-C, Shih K-N, Huang K-F, Chen C-L, Chen T-C, Chen R-H, Lin J-J and Huang H-S. Design, synthesis and evaluation of telomerase inhibitory, hTERT repressing, and anti-proliferation activities of symmetrical 1,8-disubstituted amidoanthraquinones. Eur J Med Chem. 2012; 50:102-112.

28. Perry PJ, Read MA, Davies RT, Gowan SM, Reszka AP, Wood AA, Kelland LR and Neidle S. 2,7-disubstituted amidofluorenone derivatives as inhibitors of human telomerase. J Med Chem. 1999; 42:2679-2684.

29. Perry PJ, Gowan SM, Reszka AP, Polucci P, Jenkins TC, Kelland LR and Neidle S. 1,4- and 2,6-disubstituted 
amidoanthracene-9,10-dione derivatives as inhibitors of human telomerase. J Med Chem. 1998; 41:3253-3260.

30. Perry PJ, Reszka AP, Wood AA, Read MA, Gowan SM, Dosanjh HS, Trent JO, Jenkins TC, Kelland LR and Neidle S. Human telomerase inhibition by regioisomeric disubstituted amidoanthracene-9,10-diones. J Med Chem. 1998; 41:4873-4884.

31. Zagotto G, Sissi C, Lucatello L, Pivetta C, Cadamuro SA, Fox KR, Neidle $S$ and Palumbo M. Aminoacylanthraquinone conjugates as telomerase inhibitors: synthesis, biophysical and biological evaluation. J Med Chem. 2008; 51:5566-5574.

32. Cairns D, Michalitsi E, Jenkins TC and Mackay SP. Molecular modeling and cytotoxicity of substituted anthraquinones as inhibitors of human telomerase. Bioorg Med Chem. 2002; 10:803-807.

33. Read MA, Wood AA, Harrison JR, Gowan SM, Kelland LR, Dosanjh HS and Neidle S. Molecular modeling studies on G-quadruplex complexes of telomerase inhibitors: structure-activity relationships. J Med Chem. 1999; 42:4538-4546.

34. Aoyagi Y, Kobunai T, Utsugi T, Wierzba K and Yamada Y. Establishment and characterization of 6-[[2-(Dimethylamino) ethyl]amino]-3-hydroxy-7H-indeno[2,1-c]quinolin-7-one dihydrochloride (TAS-103)-resistant cell lines. Japanese journal of cancer research: Gann. 2000; 91:543-550.

35. Yoshida M, Kabe Y, Wada T, Asai A and Handa H. A new mechanism of 6-((2-(dimethylamino)ethyl)amino)-3-hydroxy-7H-indeno(2,1-c)quinolin-7-one dihydrochloride (TAS-103) action discovered by target screening with drugimmobilized affinity beads. Molecular pharmacology. 2008; 73:987-994.

36. Fujimoto S. Promising antitumor activity of a novel quinoline derivative, TAS-103, against fresh clinical specimens of eight types of tumors measured by flow cytometric DNA analysis. Biological \& pharmaceutical bulletin. 2007; 30:1923-1929.

37. Shah A, Diculescu VC, Qureshi R and Oliveira-Brett AM. Electrochemical reduction mechanism of camptothecin at glassy carbon electrode. Bioelectrochemistry. 2010; 79:173-178.

38. Kehrer DF, Soepenberg O, Loos WJ, Verweij J and Sparreboom A. Modulation of camptothecin analogs in the treatment of cancer: a review. Anti-cancer drugs. 2001; 12:89-105.

39. Alagoz M, Gilbert DC, El-Khamisy S and Chalmers AJ. DNA repair and resistance to topoisomerase I inhibitors: mechanisms, biomarkers and therapeutic targets. Current medicinal chemistry. 2012; 19:3874-3885.

40. Aoyagi Y, Kobunai T, Utsugi T, Wierzba K and Yamada Y. Establishment and characterization of 6-[[2-(Dimethylamino) ethyl]amino]-3-hydroxy-7H-indeno[2,1-c] quinolin-7-one dihydrochloride (TAS-103)-resistant cell lines. Jpn J Cancer Res. 2000; 91:543-550.
41. Yoshida M, Kabe Y, Wada T, Asai A and Handa H. A new mechanism of 6-((2-(dimethylamino)ethyl)amino)-3-hydroxy-7H-indeno(2,1-c)quinolin-7-one dihydrochloride (TAS-103) action discovered by target screening with drug-immobilized affinity beads. Mol Pharmacol. 2008; 73:987-994.

42. Nusse R, Theunissen H, Wagenaar E, Rijsewijk F, Gennissen A, Otte A, Schuuring E and van Ooyen A. The Wnt1 (int-1) oncogene promoter and its mechanism of activation by insertion of proviral DNA of the mouse mammary tumor virus. Mol Cell Biol. 1990; 10:4170-4179.

43. St-Arnaud R and Moir JM. Wnt1-inducing factor-1: a novel $\mathrm{G} / \mathrm{C}$ box-binding transcription factor regulating the expression of Wnt1 during neuroectodermal differentiation. Mol Cell Biol. 1993; 13:1590-1598.

44. Kim S-J, Crooks H, Foxworth A and Waldman T. Proofof-principle: Oncogenic $\beta$-catenin is a valid molecular target for the development of pharmacological inhibitors. Mol Cancer Ther. 2002; 1:1355-1359.

45. Akiri G, Cherian MM, Vijayakumar S, Liu G, Bafico A and Aaronson SA. Wnt pathway abberations including autocrine Wnt activation occur at high frequency in human non-small-cell lung carcinoma. Oncogene. 2009; 28:2163-2172.

46. Takahashi-Yanaga F and Kahn M. Targeting Wnt signalling: Can we safely eradicate cancer stem cells. Clin Cancer Res. 2010; 16:3153-3162.

47. Luu HH, Zhang R, Haydon RC, Rayburn E, Kang Q, Si W, Park JK, Wang H, Peng Y, Jiang W and He T-C. Wnt/ $\beta$ catenin signalling pathway as novel cancer drug targets. Curr Cancer Drug Targets. 2004; 4:653-671.

48. Barker $\mathrm{N}$ and Clevers $\mathrm{H}$. Mining the Wnt pathway for cancer therapeutics. Nat Rev Drug Discov. 2006; 5:997-1014.

49. Kahn M. Can we safely target the WNT pathway? Nat Rev Drug Discov. 2014; 13:513-532.

50. Emami KH, Nguyen C, Ma H, Kim DH, Jeong KW, Eguchi M, Moon RT, Teo JL, Kim HY, Moon SH, Ha JR and Kahn M. A small molecule inhibitor of beta-catenin/ CREB-binding protein transcription. Proc Natl Acad Sci USA. 2004; 101:12682-12687.

51. Shultz MD, Cheung AK, Kirby CA, Firestone B, Fan J, Chen CH, Chen Z, Chin DN, Dipietro L, Fazal A, Feng Y, Fortin PD, Gould T, Lagu B, Lei H, Lenoir F, et al. Identification of NVP-TNKS656: The use of structureefficiency relationships to generate a highly potent, selective, and orally active tankyrase inhibitor. J Med Chem. 2013; 56:6495-6511.

52. Lau T, Chan E, Callow M, Waaler J, Boggs J, Blake RA, Magnuson S, Sambrone A, Schutten M, Firestein R, Machon O, Korinek V, Choo E, Diaz D, Merchant M, Polakis P, et al. A novel tankyrase small-molecule inhibitor suppresses APC mutation-driven colorectal tumor growth. Cancer Res. 2013; 73:3132-3144. 
53. Hua Z, Bregman H, Buchanan JL, Chakka N, GuzmanPerez A, Gunaydin H, Huang X, Gu Y, Berry V, Liu J, Teffera Y, Huang L, Egge B, Emkey R, Mullady EL, Schneider S, et al. Development of novel dual binders as potent, selective, and orally bioavailable tankyrase inhibitors. J Med Chem. 2013; 56:10003-10015.

54. Hufford CD, Liu S, Clark AM and Oguntimein BO. Anticandidal activity of eupolauridine and onychine, alkaloids from Cleistopholis patens. J Nat Prod. 1987; 50:961-964.

55. Prachayasittikul S, Manam $\mathrm{P}$, Chinworrungsee $\mathrm{M}$, Isarankura-Na-Ayudhya $\mathrm{C}$, Ruchirawat $\mathrm{S}$ and Prachayasittikul V. Bioactive azafluorenone alkaloids from Polyalthia debilis (Pierre) Finet \& Gagnep. Molecules. 2009; 14:4414-4424.

56. Mueller D, Davis RA, Duffy S, Avery VM, Camp D and Quinn RJ. Antimalarial activity of azafluorenone alkaloids from the Australian tree Mitrephora diversifolia. J Nat Prod. 2009; 72:1538-1540.

57. Manpadi M, Uglinskii PY, Rastogi SK, Cotter KM, Wong YS, Anderson LA, Ortega AJ, Van Slambrouck S, Steelant WF, Rogelj S, Tongwa P, Antipin MY, Magedov IV and Kornienko A. Three-component synthesis and anticancer evaluation of polycyclic indenopyridines lead to the discovery of a novel indenoheterocycle with potent apoptosis inducing properties. Org Biomol Chem 2007; 5:3865-3872.

58. Pumsalid K, Thaisuchat H, Loetchutinat C, Nuntasaen N, Meepowpan P and Pompimon W. A new azafluorenone from the roots of Polyalthia cerasoides and its biological activity. Nat Prod Commun. 2010; 5:1931-1934.

59. Banjerdpongchai $\mathrm{R}$, Khaw-On $\mathrm{P}$, Ristee $\mathrm{C}$ and Pompimon W. 6,8-dihydroxy-7-methoxy-1-methylazafluorenone induces caspase-8- and -9-mediated apoptosis in human cancer cells. Asian Pac J Cancer Prev. 2013; 14:2637-2641.

60. Shook BC, Rassnick S, Osborne MC, Davis S, Westover L, Boulet J, Hall D, Rupert KC, Heintzelman GR, Hansen K, Chakravarty D, Bullington JL, Russell R, Branum S, Wells KM, Damon S, et al. In vivo characterization of a dual adenosine A2A/A1 receptor antagonist in animal models of Parkinson's disease. J Med Chem. 2010; 53:8104-8115.

61. Chang C-C, Wu J-Y and Chang T-C. A carbazole derivative synthesis for stabilizing the quadruplex structure. J Chin Chem Soc. 2003; 50:185-188.

62. Cullen BR and Malim MH. Secreted placental alkaline phosphatase as a eukaryotic reporter gene. Methods Enzymol. 1992; 216:362-368. 